\title{
Comparative Study of the Sale and Purchase of Land Rights According to the Civil Code and the Basic Agrarian Law
}

\author{
Ayang Afira Anugerahayu Zaenal Asikin Djumardin \\ Graduate Program Student in Notary, Faculty of Law, Mataram University, Indonesia
}

\begin{abstract}
The purpose of this research is to explain and analyze the comparison of trade regulated by the Civil Code and the Agrarian Basic Law and explain and analyze the strengths and weaknesses of buying and selling regulated by the Civil Code and the Agrarian Basic Law. The research method used is the normative legal research method. The approach used is statutory, a conceptual approach and a case approach. The results of this study, First, the comparison of land buying and selling between the Law of Pedata and the Basic Agrarian Law, namely based on the meaning of land buying and selling, the terms of sale and purchase of land, the subject of law, when the sale and purchase of land and the system of publication embraced by each basic rule of land law. Second, the strengths and weaknesses contained from each rule of law include the Civil Code providing legal certainty to the group subject to the western rule of law while the UUPA provides legal certainty for Indonesian citizens with the registration of land rights. While the weakness of the civil code does not provide legal certainty for groups that are subject to customary law while the UUPA in order to obtain legal certainty requires time and costs are pretty expensive in carrying out the registration of land rights.
\end{abstract}

Keywords: Land Sale, Land Registration, Land Rights

DOI: $10.7176 / \mathrm{JLPG} / 112-07$

Publication date:August $31^{\text {st }} 2021$

\section{Introduction}

Indonesia is an agrarian country that has natural resources and a huge area. One of those natural resources island. The land is the most important natural resource to support human life. In human life, the existence of the land will not be separated from all the acts of human submission itself(Sutedi, 2019), so that the relationship of man with the land is very closely related since long ago. This is because the land is needed by every community for the survival of now or next.

Land law in Indonesia is based on Customary Law. It is contained in Article 5 of the Agrarian Basic Law (UUPA)(Boedi, 2005), which reads:

Agrarian law that applies to the earth, water, and space is the Customary Law, as long as it is not contrary to the national and state interests, which is based on the unity of the nation, with Indonesian socialism and with the regulations listed in this Law and with other regulations everything by heeding the elements based on the Law of Religion.(Boedi, 2005)

The relationship between Indonesians and earth, water and space is eternal. The land is a basic human need, serves as a place of residence, and for business activities (production factors) and therefore needs to be created a legal certainty for every land rights holder and the general public. The land is one of the objects regulated by Agrarian Law. The land governed by agrarian law is not land in various aspects, but land from juridical aspects directly related to the right to land that is part of the earth's surface stipulated in Article 4 paragraph (1) of the Basic Agrarian Law.(Arba, 2021)

The word land in the juridical sense is the earth's surface, while the right to land is the right to a particular part of the earth's surface that is limited, two-dimensional with a matter of length and width governed by the law of the land. The land is given to and owned by persons with rights provided by the UUPA is to be used and utilized.(Arba, 2021)

UUPA is based on achieving what is stipulated in Article 33 paragraph (3) Constitution of the Republic of Indonesia year 1945 the state acts as the governing body for; regulate and maintain the allocation, use, and maintenance of the earth, water, and space; determine and regulate people's relationships with the earth, water, and space; governing and determining the legal relationship between people and legal deeds concerning the earth, water, and space. The UUPA loaded the right of ownership of land containing a series of authority, obligations to be carried out, and prohibitions that the rights-holder should not carry out (Urip Santoso, 2015). Based on the hierarchy of land ownership rights, as follows: 1 . The right of the Indonesian nation to land; 2 . The right to control the state over land; 3. Indigenous people's rights; 4. Individual rights to land. The highest land tenure rights are the rights of the Indonesian nation to cover all lands in the territory of the country, which is common land and is eternal and becomes the parent for other land rights.

According to Boedi Harsono, the statement of land controlled by the Indonesian nation as a communal land shows legal relations in the field of Civil Law. However, the legal relationship is a civil relationship does not mean that the rights of the Indonesian nation are a personal ownership right that does not allow the existence of 
individual property rights. The right of the Indonesian nation is the National Land Law is owned that allows the possession of parts of the land along with property rights by individual citizens.(Urip Santoso, 2015)

The right to land is the right to authorize the holder of his rights to use and/or benefit from the land he or she is entitled to. Authority in the right to land mentioned in Article 4 paragraph (2) UUPA, namely the use of the land in question, as well as the body of the earth and water and the space on it is only necessary for the interests directly related to the land within limits according to this law and other high legal regulations.(Arba, 2021)

Based on the reference of the sense of land rights described there is the word "use" contains the sense that the right to land is used to build buildings, while the meaning of the word "benefit" contains the sense that the right to land is not to build buildings, but rather to be used to conduct agricultural activities, fisheries, farms, and plantations.

The rights to land, as referred to above are stipulated in the law of the land. There is an object of the law of the land, which is the object of land ownership. What is meant by the right to control of land is the right that contains a series of authority, obligation and or prohibition for the holder of his right to do something about the land that is rightfully.(Arba, 2021)

In the Civil Code explains the terms of the validity of the agreement. This is the basis of a contract's occurrence as a result of legal actions such as buying and selling, for example. Buying and selling can be valid if it meets the conditions stipulated in Article 1320 of the Civil Code. These conditions are:

1. The agreement between the two sides is to bind themselves.

2. The ability to do a legal action

3. A certain thing Of lawful power.

Basically, the above are the points that a seller must fulfill with the buyer in entering into an agreement and binding themselves with each other. Where the law is used as a guideline for the agreement.

In Article 16 of Law No. 5 of 1960 concerning Basic Rules of Agrarian Principles (UUPA), there is also a regulation on the rights or authorities granted to a person who uses or benefits a land through buying and selling, grants, exchanges, and will grants. In the issues related to this study, the discussion will focus on the scope of land buying and selling. Trade is an agreement by which one party binds itself to submit material, and the other party to pay the promised price.(Widjaja \& Muljadi, 2003) Based on Article 1457 of the Civil Code, it is explained that what is meant by buying and selling is an agreement with the name of the one-party (seller) binding itself to submit a material, and the other party (buyer) to pay the promised price.

The meaning of buying and selling is based on customary law, which is an act of transferring land rights that are light and cash. Terang which means the act of transfer of rights must be done before the head of a custom, which is considered to have authority as a responsible official and make legal actions carried out in the form of legal transfer. Cash means that the act of transfer of rights and payment of the price is done simultaneously.(Widjaja \& Muljadi, 2003) In customary law, the sale and purchase of land are included in the law of fixed objects or the law of land, not in the law, especially the law of.(Soekanto, 2005)

While the meaning of buying and selling based on Government Regulation No. 24 of 1997 concerning Land Registration that any transfer of land rights, whether it is a trade or transfer of other rights, must be proven by a deed made by the authorized Official to be registered at the Office of the Land Agency and for the creation of legal certainty for rights holders.

Based on Article 1457 of the Civil Code, it explains that mutual trade is based on the agreement of both parties. While the Basic Agrarian Law comes from customary law that explains related to the sale and purchase of land is not based on the agreement, the sale and purchase are made in light and cash. There is a difference in the basic basis of buying and selling between the trade regulated by the Civil Code and the Law. From the meaning of buying and selling, the author is interested in researching how to buy and sell regulated in the Civil Code and the Agrarian Basic Law, as well as the author wants to describe the strengths and weaknesses of the rules related to buying and selling between the Civil Code and the Agrarian Basic Law. Further studies are outlined in the scientific paper thesis, entitled "Comparative Study Of The Sale And Purchase Of Land Rights According To The Civil Code And The Basic Agrarian Law".

\section{Research methods}

This legal research uses normative legal research or also called doctrinal law research. The research was conducted with consideration of the legal materials used in this study is a statutory approach that is done by studying all laws and regulations related to the legal issues that are being discussed. This type of research is normative research, so in this case, the approach used is Statute Approach, Comparative Approach, Conceptual Approach.

This study uses legal material collection techniques with secondary data collection methods, namely with library studies that examine written information about the law that comes from various sources and is widely published. Various sources of written information such as legislation and court decisions (jurisprudence) which 
in this study is reviewed various laws and regulations such as the Civil Code, Law No. 5 of 1960 on Basic Agrarian Provisions (UUPA), PP No. 24 of 1997 concerning Land Registration, PP No. 37 of 1998 concerning Regulation of the Loading Department of Land Deed, and Regulation of the Minister of Agrarian State / Head of National Land Agency No. 3 of 1997 concerning Land Registration Implementation Regulations.

Analysis of legal materials is carried out by qualitative data analysis, namely analysis of primary, secondary, and tertiary legal materials to the comparison of land buying and selling based on the rules in the Civil Code and the Agrarian Basic Law so that a comparison of land sales that includes the classification of legal materials in accordance with the problems and topics of research is then adjusted to the provisions of the law, the final result of the analysis is in the form of narratives in the form of conclusions.

\section{Results and discussion}

3.1 The Strengths And Weaknesses of Land Sale Regulated by the Civil Code and The Basic Agrarian Law

A. The Strengths And Weaknesses of Buying and Selling Land Regulated by the Civil Code

1. The Power of Buying and Selling Land Regulated by the Civil Code

In the previous description has been explained the meaning of buying and selling land based on the civil code. The sale and purchase of land contained in Article 1457 of the Civil Code is "an agreement in the name of the one party binding itself to submit a material and the other party to pay the promised price". Based on the Civil Code, the sale and purchase of the land in the form of an obligatory agreement mean the trade has not transferred its property rights.(Subekti, 1996)

Considering the formulation contained in Article 1457 of the Civil Code above, it can be understood that buying and selling is a legal act that causes legal consequences. Where a legal action is an agreement or agreement in the form of a treaty that gives rise to legal consequences in the form of the birth of an obligation to give something. When viewed from the side of Article 1458 of the Civil Code, the sale and purchase of land have been considered to have occurred between the two parties after the parties reached an agreement on the object of sale and purchase of land and have obtained an agreement on the price of the object of sale and purchase, although the land has not been handed over the object of sale and price has not been paid.

This illustrates that there are two sides of civil law on the sale and purchase of land, one in the form of material law and the law of alliance. It is said that the law of materiality is due to referring to the process of buying and selling which gives rise to the right for both parties in the form of the surrender of the right of worship to a party and the payment of the selling price to the other party. On the alliance side, buying and selling is an agreement that gives birth to obligations in the form of material delivery sold by the seller and the transfer of money by the buyer to the seller. The obligation of each of the parties on a reciprocal basis must be carried out in order to meet the terms of sale and purchase of land.

This illustrates the power of land trading during the colonial agrarian law which is subject to the Civil Code. This agrarian law was made for the benefit of the invaders to make it easier to obtain land rights. According to this author is a force over the Civil Code compared to the customary law that became the basis for the Indonesian people of the son earth group during the colonial period. The process of buying and selling land that is subject to western law is regulated in the Civil Code so as to obtain legal certainty, with the certainty of this law does not cause doubt in conducting land sales.

Legal certainty is obtained only for those subject to western law. Legal certainty in the form of registration of land rights that produce proof in the form of a certificate. this registration is called Recht Cadaster or Legal Cadaster.

The process of buying and selling conducted by the community that is subject to colonial agrarian law, only by agreeing the buying and selling process can be said to have been carried out even though no payment has been made for the land purchased and there has not been a surrender of rights to the land. According to the author is a force for the rules set in the civil code because it facilitates the process of buying and selling so that anyone who is subject to the rules can do the process of buying and selling land.

In the Civil Code, the process of buying and selling is not only the stage of the formation of an agreement, but there are advanced stages to obtain legal certainty. The next stage is to make a deed of sale and purchase before PPAT in order to meet the juridical requirements in order to register the right to land for the occurrence of rights abuse so that it can obtain a certificate that has been done behind the name of the old owner to the new owner in accordance with the formulation of Article 1459 of the Civil Code. Certificates can only be given to groups subject to western law. This buying and selling process takes a short time and fast, although there is no definite attack of the time required so that with this short process also includes the strength of the buying and selling process set out in the Civil Code.

To strengthen the rules of the Civil Code must meet the terms of the validity of the agreement so that the sale and purchase agreement is considered null and void or can be canceled. The terms of validity of the agreement in accordance with Article 1320 of the Civil Code, namely the existence of agreement, proficiency, the existence of a certain thing and a lawful reason. 
In addition, the process of buying and selling according to the Civil Code is strengthened by the Principle of Consesualism contained in article 1320 and Article 1338 where we can conduct the process of buying and selling land with anyone while not violating the prevailing laws and regulations. The agreed agreement becomes law for the parties who agree to it in accordance with the meaning of the pascta sunt servanda principle. So according to the author, this becomes an ease that becomes the strength of the Civil Code in the process of buying and selling land.

2. The Weakness of Buying and Selling Land Regulated by the Civil Code

The Alliance stems from an agreement, this agreement is subject to Article 1313 of the Civil Code, which formulates the agreement is: "an agreement is an act by which one person is more binding on one or more persons". According to the author of the understanding of the agreement in this article has a weakness because the understanding of the agreement is only about unilateral agreements only, so that binding only comes from one party not from both parties. Meanwhile, what is meant by the agreement itself is to bind itself from both parties, so that it should be in the formulation of the article that is mutually binding so that it is clear that the agreement comes from both parties. so Subekti also defines a covenant is an event where one promises to another person or where the two people promise each other to carry out something.(Subekti, 1996)

An agreement arising out of an agreement and is the will of the parties. The agreement that gives rise to the alliance will not materialize if not by agreement because this agreement will become the law for the parties themselves in accordance with the formulation in Article 1338 of the Civil Code. According to the author, this can be a weakness of the Civil Code because the process of buying and selling land can be canceled unilaterally and does not require compensation because the buying and selling process has not been completed completely or in its entirety and still has the opportunity to cancel the land sale and purchase agreement.

The Civil Code during the colonial period only applies to westerners who are subject to western law, so according to this author is a weakness because the existing rules only apply to some not in its entirety so that the legal certainty provided does not apply to all circles. For people who are subject to customary law do not get legal certainty so it can give doubts for the community to conduct the process of buying and selling land.

B The Strengths And Disadvantages of Buying and Selling Land Regulated by The Agrarian Basic Law

1. The Power of Buying and Selling Land Regulated by the Uupa

After the enactment of the Basic Agrarian Law that abolished the dualism of land law in Indonesia. This has a major impact on the National Land Law in Indonesia. National Land Law is based on customary land law. In accordance with Article 5 of the Constitution that says our National Land Law is Customary Law. So the meaning of buying and selling land in the national land law is the understanding of buying and selling land according to customary law.

In accordance with the statement on the national land law on the sale and purchase of land in accordance with customary regulations, this has a very positive impact on the color of the Indonesian state at the time. Indonesians who are subject to customary law have the opportunity to obtain legal certainty over a land they purchase. Legal certainty for the people of Indonesia on the rules listed in the LAW, so according to the author, this is a force of the LAW to provide legal certainty over everything about the sale and purchase of land for the Indonesian community.

In the development of land rights owned by a person can be transferred to another party because of a legal event or legal action. The transfer of land rights is a result of a legal action, which for example is a trade. With the enactment of PP No. 10 of 1961 concerning land registration that has been replaced with PP no.24 of 1997 concerning Land Registration, the sale and purchase is carried out by the parties in the presence of PPAT in charge of making deed.(Adrian, 2014) This illustrates that the UUPA has prepared all the rules both in terms of rules and procedures for the implementation of the land sale process in detail in order to provide legal certainty. The community is easier to understand the procedure in conducting management related to the transfer of land rights by registering land rights. This is also a force owned by the UUPA in order to remain fulfilled legal certainty that wants to be fulfilled for the benefit of the people of Indonesia as a whole.

2. Disadvantages of Buying and Selling Land Regulated by THE LAW

The sale and purchase of land in the national land law is based on customary law. The transfer of land rights according to the provisions of Article 37 of Government Regulation No. 24 of 1997 concerning land registration can be done by legal action, one of which is buying and selling. In this rule has a related point of weakness in the management of land registration that can take up to 60 days. Thus, making the community sometimes reluctant to register land rights. Registration of land rights takes a long time in the process because to provide opportunities to parties who want to object to the application for registration of land rights, this is listed in Article 26 and Article 27 PP No. 24 of 1997.

In addition to taking a long time, the registration of land rights requires considerable funds both implementations organized by the government and individuals / self-help. This causes people sometimes prefer to make transactions under the hands to make it shorter and more economical. In Article 19 UUPA states about 
the obligation which one of them is about discussing related costs concerned about registration of land rights provided that the people who cannot afford to be exempt from the payment of these costs.

The exemption of fees for the poor who want to register the land is based on the principle that can be seen in Article 2 of Government Regulation No. 24 of 1997 concerning Land Registration. These principles include simple, safe, affordable, up-to-earth and open principles.

A simple principle that aims to make the provisions of the basic provisions and procedures of the land easily understood by interested parties, especially the rights holders. The principle is safe, to show that land registration is organized carefully and carefully, so that the purpose of land registration as legal certainty in order to be strong evidence. The principle of affordable, in order to provide affordable services for the weak economy in need in order to obtain legal certainty. While the principle of Mutahir, carrying out the registration of land rights by paying attention to the completeness of the system is adequate in its implementation in order to facilitate the maintenance of land registration data so as to obtain data that remains updated in accordance with the last conditions. And lastly, the principle is open, the public can get information about the data that is updated at any time so as to meet the open principle.

So, according to the author in this rule the problem of costs becomes a point of weakness in this rule that causes many people to refuse to register the rights to the land they own. This will remain a problem in the community if there is no flattening of understanding related to the procedure of registration of land rights.

Table 1 Conclusion

\begin{tabular}{|c|c|c|c|}
\hline & $\begin{array}{l}\text { Elements of Land } \\
\text { Buying and Selling } \\
\text { comparison }\end{array}$ & KUHPerdata & UUPA \\
\hline 1. & Legal Basis & $\begin{array}{l}\text { from Article } 1457 \text { to Article } 1540 \text { of the Civil } \\
\text { Code }\end{array}$ & $\begin{array}{l}\text { UUPA PP No. } 10 \text { Year } 1961 \\
\text { which was replaced with PP No } \\
24 \text { of } 1997\end{array}$ \\
\hline 2. & meaning & $\begin{array}{l}\text { the sale and purchase of land is an agreement } \\
\text { in the name of the one-party that binds itself to } \\
\text { submit a material and the other party to pay the } \\
\text { promised price }\end{array}$ & $\begin{array}{l}\text { land sale is an act of transfer of } \\
\text { land rights that are light and cash. }\end{array}$ \\
\hline 3. & Terms & $\begin{array}{l}\text { The parties who conduct the sale and purchase } \\
\text { (seller and buyer) Object of sale and purchase } \\
\text { in the form of land Cakap not in the acquisition } \\
\text { of land meets the criteria to be traded is not in } \\
\text { dispute. }\end{array}$ & $\begin{array}{l}\text { Material Terms } \\
\text { Formal Terms }\end{array}$ \\
\hline 4. & Legal subjects & $\begin{array}{l}\text { Europeans subject to European law (western } \\
\text { rights) }\end{array}$ & $\begin{array}{l}\text { Indonesians who are subject to } \\
\text { customary laws (customary } \\
\text { rights) and those subject to the } \\
\text { National Land Law }\end{array}$ \\
\hline 5. & Enactment & Before 1960 & After the enactment of the UUPA \\
\hline 6. & $\begin{array}{l}\text { When } \\
\text { happened }\end{array}$ & $\begin{array}{l}\text { The sale and purchase occurred since there was } \\
\text { agreed in accordance with Article 1458, but the } \\
\text { right to land has not been transferred, the } \\
\text { transfer of the land rights occurs if it has been } \\
\text { done behind the name of the old owner to the } \\
\text { new owner. }\end{array}$ & $\begin{array}{l}\text { After the transfer of rights and } \\
\text { registration of land rights }\end{array}$ \\
\hline 7. & $\begin{array}{l}\text { Publishing } \\
\text { System }\end{array}$ & Positive Publishing System & $\begin{array}{l}\text { Negative Publishing System with } \\
\text { Positive Publishing System }\end{array}$ \\
\hline 8. & strength & $\begin{array}{l}\text { Provide certainty to citizens who are subject to } \\
\text { western law by issued certificates. It is easier } \\
\text { to buy and sell land and conduct legal cadaster } \\
\text { in order to obtain a certificate. }\end{array}$ & $\begin{array}{l}\text { Provide legal certainty for } \\
\text { Indonesian citizens. More clearly } \\
\text { the procedure and all circles can } \\
\text { conduct a trade transaction after } \\
\text { registration of land rights. }\end{array}$ \\
\hline 9. & debilitation & $\begin{array}{l}\text { Only applies to those subjects to western law. } \\
\text { Does not provide legal certainty for those } \\
\text { subject to customary law. }\end{array}$ & $\begin{array}{l}\text { The process takes a long time. It } \\
\text { costs much money to register for } \\
\text { land rights. }\end{array}$ \\
\hline
\end{tabular}

\section{Conclusion}

The sale and purchase of land regulated by the Civil Code before the enactment of the Agrarian Basic Law has the rules listed in Article 1457 to Article 1540 of the Civil Code, meaning that the sale and purchase is an 
agreement with which one party binds itself to submit a material and the other party to pay the promised price. The buying and selling process must meet the terms of the agreement in Article 1320 of the Civil Code. The legal subject of the sale and purchase of land, namely the European group that is subject to western law, applies in the period before the enactment of the LAW, namely before 1960. In accordance with Article 1458, the trade occurs since the agreed word, but the right to land has not been transferred. The transfer of land rights occurs if the name of the old owner becomes the new owner, the registration of land rights is used positive publication system that considers the owner or who is legally entitled to the land whose name is listed in the certificate. The sale and purchase of land after the enactment of the Agrarian Basic Law is regulated in the UUPA and PP No. 10 of 1961 which was replaced by PP No.24 of 1997, land sale is an act of transfer of rights that is bright and cash, which must meet the requirements formal and material requirements. Uupa was enacted to equalize to obtain land rights and provide justice for the Indonesian government that is subject to customary laws and groups subject to the National Land Law. The sale and purchase of land is said to have occurred after the transfer of rights and the registration of land rights. The system embraced in the registration of the LAW is a negative publishing system with positive consequences.

The strength of land buying and selling regulated in the Civil Code is to provide certainty to citizens who are subject to western law with the issuance of certificates other than that by buying and selling land based on the Civil Code is easier the process of buying and selling land and takes a shorter time while the weakness is only applicable to those who are subject to western law that is European and besides the weakness can not provide legal certainty for indigenous peoples who are subject to customary law. The power of land buying and selling agrarian basic law is to provide legal certainty for Indonesian citizens who are subject to customary law in addition to the strength is more explicit procedures for buying and selling land and anyone can do a trade transaction while the weakness is that it requires a long process and requires a relatively expensive cost so that there are still many who do land buying and selling transactions underhand to save costs.

\section{References}

Adrian, S. (2014). Peralihan Hak atas tanah dan Pendaftarannya. Jakarta: Sinar Grafika.

Arba, M. (2021). Hukum Agraria Indonesia. Sinar Grafika.

Boedi, H. (2005). Hukum Agraria Indonesia, Sejarah Pembentukan Undang-Undang Pokok Agraria, Isi dan Pelaksanaannya. Djambatan. Jakarta.

Soekanto, S. (2005). Hukum Adat Indonesia.

Subekti, R. (1996). Hukum Perjanjian, St. XIV, Intermasa, Jakarta.

Sutedi, A. (2019). Peralihan hak atas tanah dan pendaftarannya. Sinar Grafika.

Urip Santoso, S. H. (2015). Perolehan hak atas tanah. Prenada Media.

Widjaja, G., \& Muljadi, K. (2003). seri hukum perikatan JUAL BELI. Jakarta, PT. RajaGrafindo Persada. 